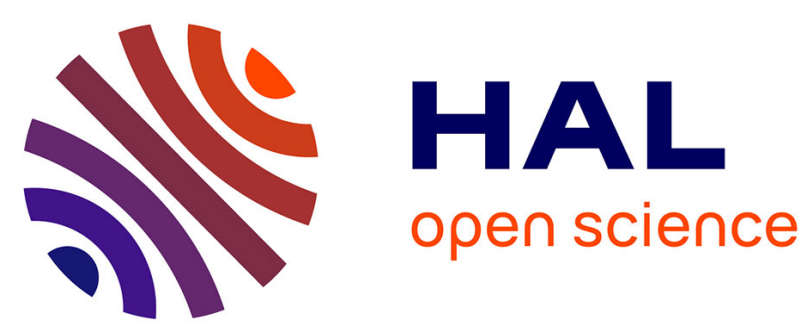

\title{
LEGAL FORM OF ACTIVITY OF LEGAL ENTITIES OF CORPORATION TYPE
}

\author{
Anatoliy Kostruba, Farkhad Karagussov
}

\section{To cite this version:}

Anatoliy Kostruba, Farkhad Karagussov. LEGAL FORM OF ACTIVITY OF LEGAL ENTITIES OF CORPORATION TYPE. Journal of the National Academy of Legal Sciences of Ukraine, 2019, 26 (2), pp.131-146. 10.31359/1993-0909-2019-26-2-131 . hal-02377529

\section{HAL Id: hal-02377529 https://hal.science/hal-02377529}

Submitted on 23 Nov 2019

HAL is a multi-disciplinary open access archive for the deposit and dissemination of scientific research documents, whether they are published or not. The documents may come from teaching and research institutions in France or abroad, or from public or private research centers.
L'archive ouverte pluridisciplinaire HAL, est destinée au dépôt et à la diffusion de documents scientifiques de niveau recherche, publiés ou non, émanant des établissements d'enseignement et de recherche français ou étrangers, des laboratoires publics ou privés. 


\title{
УДК 342
}

\section{DOI: 10.31359/1993-0909-2019-26-2-131}

\section{фархад Сергійович Карагусов \\ Iнститут приватного права \\ Каспійський університет \\ Алмати, $\rho_{\text {еспубліка Казахстан }}$}

\section{Анатолій Володимирович Коструба \\ Кафедра иивільного права Прикарпатський наиіональний університет імені Василя Стефаника

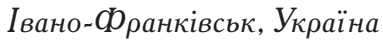

\section{ОРГАНІЗАЦЙНО-ПРАВОВІ ФОРМИ ДІЯЛЬНОСТІ ЮРИДИЧНИХ ОСІБ КОРПОРАТИВНОГО ТИПУ}

\begin{abstract}
Анотація. Підприємницька діяльність в Украӥні почала формуватися в умовах відсутності попереднього досвіду ї̈ правового регулювання у зв 'язку із тривалим сочіалістичним періодом. Відносини між фізичними особами та організаціями, які об'єдналися в одну корпорацію потребують особливого регулювання, і одним із засобів, за допомогою якого стало можливим регулювання відносин щодо створення та діяльності корпорацій, є конструкція юридичної особи. Тому основна мета роботи полягає у виявленні особливостей організаційно-правової форми діяльності юридичних осіб корпоративного типу. Аналіз норм чинного законодавства, які містять термін «організачійно-правова форма», показує неоднозначність його застосування у контексті різних правових норм Загальновідомо, щуо до змісту корпоративних правовідносин включаються не лише корпоративні права, але й відповідні корпоративні обов'язки учасника товариства. Встановлено, щчо чинне ичивільне законодавство України не надає нормативного визначення організаційно-правової форми юридичних осіб, не встановлює критеріїв ї̈ формування. На підставі ретроспективного аналізу нормативно-правових актів проаналізовано трансформачію законодавчого підходу до визначення правової природи корпоративних прав - від визнання за ними природи абсолютного речового права до визначення їх як симбіозу майнових і немайнових прав, зумовлених володінням часткою у статутному капіталі юридичної особи корпоративного типу. Виявлено, щяо господарським кодексом Украӥни закріплені основні форми в яких діють суб'єкти господарювання (підприємства колективної власності, господарськи товариства, приватні підприємства, фермерське господарство, іноземне підприємство тощо). В роботі проведена класифікація організаційно-правових форм юридичних осіб, які групуються за відповідними критеріями. Але критерієм розмежування та класифікації певного кола організаційно-правових форм юридичних осіб виступає правовий режим майна юридччної особи створеної в той чи іншій організащійно-правовій формі.
\end{abstract}

Ключові слова: корпоративні правовідносини, кооперація, самоорганізація моделей юридичних осіб, акціонерне товариство. 
Farkhad S. Karagussov

Institute of Private Law Caspian University Almaty, Republic of Kazakhstan

Anatoly V. Kostruba

Department of Civil Law Vasyl Stefanyk Precarpathian National University Ivano-Frankivsk, Ukraine

\title{
LEGAL FORM OF ACTIVITY OF LEGAL ENTITIES OF CORPORATION TYPE
}

\begin{abstract}
In Ukraine, entrepreneurship started forming in the absence of the previous experience of its legal regulation in connection with the long socialist period. The relationship between individuals and organisations that have merged in one corporation needs special regulation, and one of the means by which it became possible to regulate relations on the creation and operation of corporations, is the construction of a legal entity. Therefore, the main purpose of the work is to identify the legal form of the activities of legal entities of a corporate type. The analysis of the norms of the current legislation, which contain the term "legal form", shows the ambiguity of its application in the context of different legal norms It is well-known that the content of corporate legal relationships includes not only corporate rights, but also the corresponding corporate responsibilities of company's member. It is established that the current civil law of Ukraine does not provide normative definition of a legal form of legal entities, does not establish the criteria for its formation. On the basis of a retrospective analysis of normative legal acts, the transformation of the legal approach to the definition of the legal nature of corporate rights has been analysed - from the determination of the nature as the nature of absolute substantive law to the definition of it as a symbiosis of property and non-property rights caused by the ownership of a share in the authorised capital of a legal entity of a corporate type. It has been found out that the economic code of Ukraine fixed the main forms within which economic entities (collective-ownership enterprises, economic companies, private enterprises, farming, foreign enterprise, etc.) operated. The classification of legal forms of legal entities, which are grouped according to the relevant criteria, has been carried out. But the criterion for the delineation and classification of a certain range of legal forms of legal entities is the legal regime of property of a legal entity established in one or another legal form.
\end{abstract}

Keywords: corporate legal relations, cooperation, self-organization of models of legal entities, joint-stock company.

\section{INTRODUCTION}

Legal entities as legal fiction in the absence of a physical form of its existence, acquires a different, abstract reflection of the ordering of its internal content. The combination of cumulative will and capital of a human being in the integral legal structure of a legal entity, with the separation of the legal interest of such a legal entity from the interest of individuals who created it, requires the formation of features, the implementation of which compensates the lack of the specific in the structure of a 
legal entity. Traditionally, in the theory of civil law, such features are organisational unity, ringfenced assets, independent legal liability, participation in civilian turnover on own behalf [1].

At the same time, modern development of institution of legal entity shows that the classical formula of the characteristics of a legal entity requires meaningful improvement. The abstraction of the legal entity from the human substrate offset its importance in the apparent control of a person by its activities. Conditionality of consequences of activity of a legal entity on the behaviour of an individual who is behind her "veil" is beyond doubt. Property liability of a legal entity is not personalised in relation to it. An individual influencing the nature of the legal entity's activity, its decisions-making, and the consequences of them, also takes responsibility for such activity. Consequently, the liability of a legal entity is limited in nature, the threshold of which is determined by a size of its authorised capital or a size of contributions of its participants (founders) to ensure the activity of the legal entity. Exceeding the established threshold of a size of a harm done receives subsidy compensation at the expense of the participants (founders) of the legal entity.

Also, it is worth to mention that connection of a human with a legal entity is wider than just creation of a latter. Legal interest of participants of corporate legal relations with regard to a legal entity and its activities is maintained throughout the life of a legal entity. The implementation of such interest implies legal possibilities of protecting it in a jurisdictional or non-jurisdictional form. For example, an application to a court with a derivative action for the invalidation of an agreement entered into with a legal entity, the participant (founder) of which is the plaintiff.

In this case, the autonomy of participation of a legal entity in civilian turnover is offset by legal possibilities of corporate relations associated with it, participation of individuals to act in a procedural manner independently on behalf of a legal entity, but in their own interests. Thus, the autonomy of participation of a legal entity in civilian turnover is not absolute. Such autonomy is provided not only by functioning of bodies of a legal entity, but also by initiative of participants of corporate legal relations, who consider it advisable to achieve the effectiveness of corporate governance by a legal entity through committing independent legal actions in its favour.

The autonomy of a legal entity is completely offset if ownership of its corporate rights belongs to such entity as the state.

It is brightly fixed in the Law of Ukraine "On management of state-owned objects". According to the article 11 of this legislative act, a state-owned joint-stock company formed in the process of transformation of a state-owned enterprise, $100 \%$ of whose shares belongs to the state, has no right to give the property assigned to it free of charge to other legal entities or citizens, except in cases stipulated by law. To dispose of property belonging to capital assets, a state joint-stock company has the right only with the prior consent of a body that manages corporate rights of the a and only on a competitive basis, unless otherwise provided by law. A state-owned joint-stock company has the 
right to dispose in another way of property belonging to capital assets only within the limits of authority and in the manner prescribed by law [2].

In addition, state-owned commercial enterprises and state-owned enterprises which, in accordance with Article 1 of the Law of Ukraine "On Scientific and Scientific and Technical Activity" are classified as scientific institutions, as well as scientific and technological complexes, which are based on state ownership, are required not less than $50 \%$ of net profit from its activities to direct to the initiation of scientific and scientific and technical activities, the financing of innovations and the expansion of its own material and technical base.

Consequently, the relations between a legal entity and its founder (participant), conditionality of its legal behaviour by his/her will is obvious.

\section{MATERIAL AND METHODS}

Theoretical methods of research have determined the features of legal form of activity of legal entities of corporative type. Finally, limitation of the autonomy of a legal entity as a subject of civil law is regulative requirements regarding dividend payments. Using method of legal comparison, it has been established that economy code, depending on means of foundation and formation of the statutory fund in Ukraine, divides enterprises into unitary and corporate ones. A unitary enterprise is created by one founder, who allocates the necessary property, forms a statutory fund in accordance with the law that is not divided into shares, approves a charter, distributes revenues, directly or through the manager appointed by a founder, manages the enterprise and forms its labour collective on the basis of labour hiring, solves the issue of reorganisation and liquidation of an enterprise. State, communal, enterprises based on a property of a citizen's association, a religious organisation or a private property of the founder are unitary. As it is seen, a corporate enterprise differs from the unitary by a number of founders. A corporate enterprise, unlike the unitary, is formed by two or more founders. But in some cases, a corporate enterprise can be formed by one person. Therefore, this criterion may not always be used to differentiate these concepts.

Using method of analysis, it has been established that economic companies, in the authorised capital of which are corporate rights of the state, by May 1 of the year following the reporting, make a decision on the deduction of not less than $30 \%$ of net profit to pay dividends. Economic corporations, $50 \%$ and more of the shares (stakes) of which are in the authorised capital of economic partnerships, the state share of which is $100 \%$, pay dividends directly to the State Budget of Ukraine in the period no later than July 1, of the year following the reporting year, in the amount of base norms of deduction of the share of profit directed on payment of dividends, but not less than 30 $\%$, in proportion to the size of the state share (stake) in the authorised capital of economic partnerships, the shareholder of which is the state and owns they control a block of shares. At the same time, the number of dividends on the state share untimely paid 
by an economic company in authorized capital of which there is the corporate rights of the state, and an economic company 50 and more percent of shares (stakes) of which are in the authorised capital of an economic company, in which share of the state is 100 $\%$, the central executive body, which ensures the formation and implementation of state policy in the field of management of state-owned objects, is charged a penalty payable to the general fund of the States of the Ukrainian budget in calculating the double discount rate of the National Bank of Ukraine from the amount of the underpayment calculated for each day of delay of payment starting from the next day after the due date and on the day of payment inclusive.

\section{RESULTS AND DISCUSSION}

\subsection{Features of legal form of a legal entity}

In civil turnover a legal entity has own image. It exists in a certain legal form. Form is a way of organizing and a way of being of an object, process, phenomenon. It is the internal ordering of its content which is determined by functionality of a legal entity, the specifics of its substantive activity. Traditionally, in the theory of civil law, this phenomenon was called the legal form of a legal entity. This phenomenon means external form of organisation of activity of a legal entity in civil turnover. This form is a legal model of the organisations of the legal entity's activity that absorbs the essential features of the latter, which ensures its existence in the legal environment. Thus, a legal entity, depending on the purpose of its activities, the legal regime of its property, the forms of participation of participants (founders) in its activities, obtains the appropriate legal possibilities of functioning, which, in aggregate order, finds its consolidation in a separate identified form.

In this context O.R. Kibenko notes that legal parameters of legal forms of a legal entity include: the procedure for company establishment, legislative restrictions on the circle of participants; composition of constituent documents; the procedure for making changes to them; requirements of the legislation on capital (minimum size, order of formation, types of deposits, support of a size of own capital); legal regime of property (the possibility of allocating the share of a participant); legal status of a participant of a company (rights, duties, responsibility for obligations of a company); publicity of activities, order of reorganisation and liquidation, etc. [3].

It is needed to state that the current civil legislation of Ukraine does not provide normative definition of the legal form of legal entities, does not establish criteria of its formation. The development of the modern national legislation is characterised by individual normative and legal regulation in the field of relations under study.

Almost every type of a legal entity, which is mediated by one or another sphere of economic activity, is created in the legal form, which is established by a special act of the civil legislation of Ukraine.

Such regulation is resulted in the individual establishment of a certain legal form in relation to one or another type of legal entity by special regulatory acts of the legis- 
lation of Ukraine. Identification by acts of their respective legal features.

Thus, the Law of Ukraine "On Banks and Banking" [4] stipulates that banks in Ukraine are created in the form of a joint-stock company or a cooperative bank. The Law of Ukraine "On Consumer Cooperation" [5] states that the consumer society as the primary link of consumer cooperation is the organisation of citizens who, on the basis of voluntary membership and mutual assistance at the place of residence or work, are united for joint management in order to improve their economic and social status.

In its turn, public associations are created as a public organisation or a public union, as described in Article 1 of the Law of Ukraine "On Civil Associations" [6]. The Law of Ukraine "On Trade Unions, Their Rights and Guarantees of Activity" refers to public associations such legal form of their activities as a trade union that means a voluntary non-profit organisation, uniting citizens associated with common interests by the nature of their professional (labour) activity (training) [7].

Its individual form is political party as a lawful voluntary association of citizenssupporters of a national program of social development that aims to promote the formation and expression of political will of citizens, participate in elections and other political events [8]. A charitable organisation can be established as a charitable company, a charitable institution or a charitable foundation [9].

The tradition of independent legal regulation of activities of certain types of legal entities, the establishment of their legal forms, is not new for a national legislation. The analysis of the legislation of foreign jurisdictions of certain European countries, in particular France and Germany, confidently allows to assert the independent legal regulation of the activities of non-commercial legal entities, certain types of business entities, in particular banks. There is no doubt that the legal regulation of activities of certain types of legal entities requires independent regulatory consolidation. Within the limits of a single codified act legal rules cannot be systemised, which in details define a separate sphere of legal regulation. In the process of codification, the foundations of legal regulation of an array of social relations are established, the methodological principles of branch formation are determined. It determines the contours of further streamlining of relations with other legal acts, norms of which may be of a complex nature, contain a public-legal order that is atypical for the corresponding act of codification. Consequently, autonomous legal certainty of legal forms of legal entities is not so much a question of methodological correctness, as the quality of legal technique of the legislator. It is worth to agree with the thought of O.I.Zozulyak that the approach of a legislator to differentiation of legal forms of legal entities is unclear, but it makes it possible to state that almost every law produces a new legal form, while the majority who claim to be independent are often allocated artificially, when there are in fact no clear civilist attributes that would influenced a particular feature or exclusivity of their position as subjects of civil law and the possibility of separation into an independent legal form. As an example, the author takes charitable organisations, political parties, trade unions, etc., which by their nature are public organisations. Or there is another 
example: housing and building, housing, garage cooperatives, which by their legal nature are consumer societies but create an independent legal form [10].

In our opinion, it is worth noting that according to Article 83 of the Civil Code of Ukraine, legal entities are formed in the form of associations, institutions and in other forms established by law. A company is an organisation created by combining persons (participants) who have the right to participate in this partnership and can be created by one person.

In its turn, an institution is an organisation created by one or by several persons (founders) who do not take part in its management by combining (allocating) their property to achieve the goal determined by the founders at the expense of this property.

Companies engaged in entrepreneurial activity in order to obtain a profit and its subsequent distribution among participants (business partnerships) can be created only as economic partnerships (full partnership, limited partnership, limited liability company, joint-stock company) or production cooperatives.

Non-entrepreneurial companies are companies that do not intend to make a profit for its subsequent distribution among the participants. Features of a legal status of certain types of non-business companies are established by law.

The conducted analysis demonstrates that non-business company is in its essence public association that act in legal form of public organisation, public association, etc. [6]. However, the Civil Code of Ukraine does not use this conceptual apparatus. For today, a significant part of the legal forms of legal entities that define and ensure activity of entities is not correlated with the main codified act of the civil law of Ukraine. The unclear moment in the Civil Code of Ukraine is the ratio in of such categories as a company that is considered as the legal form of a legal entity and business partnerships that can be created only as economic partnerships (full partnership, limited partnership, limited liability company, joint-stock company) or production cooperatives, as well as non-entrepreneurial societies with cooperatives, except for production associations, citizens' associations with public associations, etc.).

Another unclear and even mistaken point is classification of legal form given in the Commercial Code of Ukraine.

Firstly, the Commercial Code of Ukraine does not provide legal forms for the implementation of non-commercial economic activities. Article 53 of the Code states that non-commercial activities may be carried out by economic entities on the basis of ownership or right of operational management in organisational forms determined by an owner or an appropriate management body or local self-government body taking into account the requirements provided for by this Code and other laws, but there is no corresponding list.

Secondly, these acts of the legislation of Ukraine uses the notion of legal form, associations of enterprises, a legal status of which is not defined either by the Civil Code of Ukraine or by other acts of civil legislation of Ukraine. Even in the Commercial Code of Ukraine, there are only declarative provisions, which informatively reveal the defini- 
tion of this legal phenomenon, without indicating peculiarities of the functioning of its mechanism.

Finally, the Commerciale Code of Ukraine consolidates the main forms of operation of economic entities (collective-ownership enterprises, economic partnerships, private enterprises, farmers, foreign companies, etc.). The systematic analysis of the above (the provisions of Section 2 of the Commercial Code of Ukraine) allows us to conclude that there is no logic for constructing such a system of legal forms. Their multiplicity and controversy within the same species exclude the possibility of forming certain standards for their legal verification and the creation of structural construction of legal forms.

Consequently, the legal certainty of legal forms of legal entities is required to be streamlined and classified according to the established criteria in the codified act of the civil legislation of Ukraine.

\subsection{Pecularaties of factors necessary to systemise the legal forms}

The important factor of the process of systematisation of legal forms of legal entities is features that in total influence their classification.

Firstly, such feature through which the choice of a legal form and the respective classification of legal entities takes place, is a form of capital attraction, which corresponds to the sign of a legal entity as the separation of its property.

Secondly, the responsibility of a legal entity as a reflection of a corresponding feature of a legal entity, because it permits establishment of separate forms of organisation and activities of legal entities with taking into account this criterion.

Thirdly, the purpose of activity of a legal entity is specified through a form of its activity within which the purpose of its creation is implemented.

Fourthly, the corporate nature of an organisation of relations "participant (founder) / legal entity" that provides the opportunity to separate forms of activity of legal entities by a type.

Finally, the procedure of managing a legal entity is a feature that allows the classification of legal entities within the appropriate legal form.

In addition, the necessity of certainty of legal forms puts on the agenda the issues of the exhaustion of types of legal forms in the acts of civil legislation of Ukraine or in the open list. The most widespread is the view of scientists about the closed (exhaustive) list of legal forms of legal entities. O. I. Zozulyak paid considerable attention to this issue. Studying the theoretical aspects of non-entrepreneurial legal entities, the author analyses the scientific developments of both domestic scientists and scientists of Russia and Belarus, who share the opinion regarding the expediency of an exhaustive list of legal forms. O. I. Zozulyak writes that, in particular, in Russian civil law, according to E.O. Sukhanov, there is no content in the emergence of new legal forms. According to S. Ananyach and T. Soifer, the principle of unity and differentiation in the civil law of Belarus, requires clearly formulating the legal forms of legal entities, reflecting all the 
necessary signs in the relevant norms [10]. These considerations concerning the closed list of legal forms are supported by O. I. Zozulyak, considering that such characteristic is an essential component of successful modernisation of legislation in this sphere.

The author has a different point of view on this issue. It is based on the need for an extended interpretation of Article 83 of the Civil Code of Ukraine.

Formally, such a position corresponds to the normative composition of the construction of this article of the Civil Code of Ukraine, part one of which provides that legal entities may be formed in the form of associations, institutions and other forms established by law. Attention should be paid to a certain discrepancy between the actual content of the norm and its wording, which is in that the verbal expression is more narrow than the thought that was laid upon it by the lawmaker in the process of norm designing. The reason is the presence of close in the meaning rules, which allow to expand the boundaries of the rules of the regulations that is being interpreted. In addition, the verbal formulation due to lexical defects does not sufficiently express the idea of the legislator.

Methodological paradigm of private-legal regulation of social relations is devoid of normatively defined limits of its existence. Freedom of contract as a principle gives parties autonomy of will in the regulation of civil relations. Parties of a contract may depart from the provisions of acts of civil law and settle their relations at their discretion. Such discretion penetrates all spheres of relations, which are regulated by civil law that gives impetus to its development. The institute of the legal entity is not an exception. Its nature as a social phenomenon, created to implement the interest of individuals, implies the existence of a common will in its autonomous expression. The effectiveness of this social organism is revealed through the active behaviour of a person without which a legal entity is not functional. Therefore, as noted earlier, a legal entity as a common will of a certain circle of persons involves the establishment of an individually voluntary individual coordination through a collective for the formation of its will unity, through which the legal entity individualises itself in space. Forms of organisation of such "common will" are various. Self-regulation of civil legal relations is a factor of improving the forms of organisation of legal entities, the emergence of its new models. Thus, as a result of adaptation of existing forms to emerging needs, a form of a limited liability company appears.

The researcher of this issue V.O. Gorlov notes, “...By the end of the 19th century, there was a practical need for a new form of commercial activity (in a new combination of company elements), which was caused by the inflexibility and strict regulation of joint-stock companies and the inability of the widespread use of full and limited companies. Sometimes a narrow circle of people, who want to do business, are ready to combine part of their property, but do not want to risk the responsibility that goes beyond this property, forming a full company. At the same time, it is not suitable for them designed to attract capital of a large number of individuals joint stock company, the insti- 
tution of which, moreover, is associated with compliance with the set of formalities. Obviously, the way out of this provision is to create a new form of a friendly association..." [11].

As researches noted, tight links between organisational forms of trade associations that exist in civil law have made it easy for a legislator to create, recognise and develop transitional forms of social associations that successfully combine the characteristics of full companies and joint-stock companies.

The mentioned above is happening now. In the context of Article 83 of the Civil Code of Ukraine, the Law of Ukraine "On Cooperation" establishes such form of legal entity as a cooperative [12]. Non-commercial companies, as Article 85 of the Civil Code of Ukraine mentions, carry out their activities in the form of a public association and a public union, other legal forms specified by special acts of the legislation of Ukraine, which, in accordance with Article 2 of the Law of Ukraine "On Civil Associations" are not covered by this law [13]. These are political parties, religious organisations, nonprofit associations formed by acts of state authorities, other state bodies, authorities of the Autonomous Republic of Crimea, local self-government bodies, associations of local self-government bodies and their voluntary associations, self-regulatory organisations, organisations that carry out professional self-government, non-profit associations (which are not public associations) formed on the basis of other laws.

Determining the legal framework for the implementation of constitutional rights in one or another sphere of public life, the adoption of a separate legislative act of a relevant subject focus allows to regulate these social relations, including foreseeing the organisational forms of activities of other participants in the legal relationship than individuals.

Under such conditions, an open list of organisational forms of activity of legal entities is justified, because within the Civil Code of Ukraine it will be erroneous to define forms of such legal entities, a significant number of which has a public and law scope for its application. In addition, in the context of European integration processes, which are held in our society, it is an open list of legal forms that allows the positive borrowing of stable legal constructions from neighbouring law and order, self-organisation of models of legal entities in open systems.

\subsection{Features of systematisation of legal forms}

At the same time, it is urgent to streamline existing legal forms of legal entities, to systematise them on the basis of the classification of legal entities, which will contribute to the modernisation of the design of the latter and elimination of the phenomenon of fluctuations in the normative dimension.

Any classification of a certain totality of objects begins with the choice of criteria, in which at the first stage most often explicit, external or internal signs are selected and applied. Typically, their choice is rather free and is formed on concretely developed pragmatic circumstances or is delegated along with a task (the first level of detailing). 
The legal form is the basic criterion of the process of systematisation that provides their functional quality reflected in corresponding models of legal entities.

A limited liability company may serve as an example of such a model of the legal entity. Other models of legal entities, which functionally correspond to the content of this legal form, synthesise another model of generalization - a class. A limited liability company, company, limited partnership, superadded liability company are very weakly correlated with each other, but have a criterion of system unity which is a way of acquiring the right of share participation in them. Thus, legal entities within this legal form are systematised into a class of non-equity companies. The nature of the way of acquiring the right of share participation consists in the formation of the authorised capital, size of which consists of the nominal value of the shares, each of which is formed by the contribution of participants in the property and non-monetary (nonproperty) form.

Other models of the legal entity of mentioned level of detailing in dependence on the chosen way of acquiring the right of share participation are represented by models of legal form of public and private joined-stock company.

In law of Germany and France this is limited partnership with hares and joined-stock limited partnership. In the US and UK law, a simplified joint-stock company, a corporation, a limited liability company, etc. They form a class of joint stock companies.

Finally, the third group of legal entities has legal form of the form of a production cooperative, a service cooperative, a consumer cooperative (consumer partnership), a law office and a lawyer association. In the law of the USA and the United Kingdom, there are general partnership (GP), limited partnership (LP), limited liability partnership (LLP). As well as the European Cooperative Society (SCE), the formation and activities of which are established by Council Regulation (EC) No. 1435/2003 of 22 July 2003 [14], is classified as a cooperative society. It is characterised of not only the way of acquiring the right of share participation, which is characterised by the association of contributions of members of the cooperative society. Its functional property, which creates the corresponding class, is in the participation of members of the cooperative in their activities.

Thus, it is possible to identify the fundamental properties that are used in the form of qualitative criteria for classification. In general, they characterise internal condition of the system, reflect the nature of its origin, select the most important characteristics. These criteria are used most consistently, reasonably and convincingly in the selection, formulation and formation of groups according by the class criterion. They unite, identify and position totalities of objects by criteria, directly or indirectly point to the unity of origin, the common nature or the homogeneity of the processes of their occurrence, formation, development (the second level of detailing).

This approach allows classifying other legal forms of legal entities, which are grouped into a corresponding class by criteria, the sign of which is the lack of commercial outcome of the legal entity. Such legal forms are public organisation, public 
association, political party, associations of local self-government bodies and their voluntary associations, self-organising body of the population, association of coowners of a multi-apartment building, charitable organisation, charitable institution, charitable foundation, arbitral tribunal.

Within the second level of detailing these legal forms are classified in relation to direction of implementation of a purpose of their activity. Thus, public organisation, public association, association of co-owners of a multi-apartment building, arbitral tribunal, associations of local self-government bodies and their voluntary associations are created in order to implement and defend rights and freedoms, satisfaction of interests of a society, in particular economic, social, cultural, ecological, and other interests, including their members'. The criterion of classification of these legal forms is a private interest of such association. At the same time, such privacy of interest is ensured by corporativity of only those individuals who are members of public associations. In other words, for the given legal forms, a model is characteristic in which the private behaviour of members of a public association is ensured by their private interest.

In its turn, a political party is voluntary association of citizens - supporters of a certain national program of social development, which aims to promote the formation and expression of political will of citizens, participates in elections and other political events.

The rights of citizens to freedom of associations in political parties to implement and defend own rights and freedoms and satisfy political, economic, social, cultural and other interest is determined and guaranteed by article 36 of the Constitution of Ukraine [15].

Political parties contribute to formation and expression of political will of citizens, participate in election. Consequently, the creation of a non-commercial legal entity in legal form of political party is the form of corporative concentration that aimed at public interest.

In its turn, for this legal form, the models of its functioning are built in such way that private behaviour of members of political part implements public interest.

Concerning charitable organisations (charitable company, charitable institution, charitable foundation), model of organisation of their activities has fundamental differences from the above analysed.

Firstly, it is necessary to emphasise that the purpose of charitable organisations cannot be the making and distribution of profits among founders, members of management bodies, other related persons, as well as among employees of such organisations [16].

Secondly, purposes of charitable activity is to provide assistance to promote the legitimate interests of beneficiaries in the field of charitable activities, and supporting these areas in favour of the public interest.

The Law of Ukraine "On Charity Work and Charity Organisations" determined spheres of charitable activities. These are: 1) education; 2) health care; 3) ecology, 
environmental protection and protection of animals; 4) prevention of natural and technogenic catastrophic crashes and liquidation of their consequences, the help injured with catastrophic crashes, armed conflicts and accidents, and also to refugees and persons who are in difficult vital circumstances; 5) guardianship and care, legal representation and legal assistance; 6) social protection, social security, social services and overcoming of poverty; 7) culture and art, protection of cultural heritage; 8) Science and scientific research; 9) sport and physical culture; 10) human and civil rights and fundamental freedoms; 11) the development of local communities; 12) the development of international cooperation of Ukraine; 13) stimulation of economic growth and economic development of Ukraine and its individual regions and competitiveness of Ukraine; 14) promotion of national, regional, local and international programs aimed at improving the socio-economic situation in Ukraine; 15) promotion of defence capability and mobilization readiness of the country, protection of the population in emergency situations of peaceful and martial law [16].

The above shows that the model construction of the functioning of such legal form ensures the public behaviour of the third parties (philanthropist) in implementation of the private interest of the beneficiary of public importance.

Unlike the above listed legal forms of business (commercial) legal entities mentioned are characterised by another organisation of their activities [17-20]. In addition to a non-entrepreneurial component, which eliminates the need for capital unification, the legal forms of legal entities are individualised by the form of participation of their founders (participants) in the activities of such legal entities. If for entrepreneurial companies such form of participation of founders (participants) in their activity is based on indirect management through the creation of a corresponding executive body of a legal entity, participation in the regulation and control over the activities of such an executive body, in particular through participation in the work of the supervisory board, general meeting of participants, etc. for legal forms of legal entities that are deprived of the business component, the participation (founders) of the participants (founders) in their activities is of a direct nature.

Thus, public association, which is created to implement and defend rights and freedoms, to satisfy interests of society, in particular, economic, social, cultural, ecological and other interests, objectively requires participation of its members in activity of an association, management of its affairs, including by voting at meetings of members, expressing own opinion, making suggestions on the directions of activity and development of a legal entity, etc.

In addition, the criterion for the delineation and classification of the given range of legal forms of legal entities is the legal regime of a property of a legal entity established in one or another legal form.

The legal regime of a property of entrepreneurial companies gives the opportunity to divide them among the founders (participants). Article 111 of the Civil Code of 
Ukraine established that “A legal entity's property remained after meeting creditors' demands (including taxes, fees, a single contribution to compulsory state social insurance and other funds to be paid to the state or local budget, the Pension Fund of Ukraine, social insurance funds), shall be transferred to its members unless otherwise established by the constituent documents or the law." Analogical by the logic of construction of normative material provisions are in all special legislative acts that regulate activity of entrepreneurial companies in Ukraine. Thus, according to article 29 of the Law of Ukraine "On Cooperation", property remained after meeting creditors' demands, paying shares to members of cooperative and payments on shares, cooperative payments, wages, settlements with a cooperative association, of which it is a member, is divided among the members of the cooperative in accordance with the procedure established by the charter [12].

In its turn, the legal regime of property of legal entities created in legal forms that are inherent in non-entrepreneurial companies limits their ability to implement the right guaranteed by Article 41 of the Constitution of Ukraine, Article 317 of the Civil Code of Ukraine.

For such legal forms of legal entities, a rule is established that, in the event of their self-dissolution (liquidation), property and funds, remained after meeting creditors' demands, are transferred to statutory or charitable purposes to another (several other) public associations or are credited to the state and local budgets.

\section{CONCLUSIONS}

Therefore, joint-stock, non-joint stock companies and cooperatives are grouped into entrepreneurial or commercial associations. In turn, public associations and charitable organisations are united by the notion of non-entrepreneurial society. The only criterion for their unification is the purpose of activity.

The aforementioned set of legal forms of legal entities is objectively systematised through the parameter, which evaluates their objective components, clearly outlines the constructive characteristics and investigated elements that are present in the corresponding sets of legal entities within this group.

The character of relations of researched legal entities (their legal forms) with their participants (founders), purpose of their participation has a synergistic effect. Through the disclosure of the legal nature of a corporation and the establishment of its features, the corporate unity of business and non-entrepreneurial societies and their meaningful difference from institutions have been proven.

The above demonstrates that the whole set of legal forms of corporate legal entities is classified according to the relevant criterion that ensures their group identity (jointstock and cooperative societies, public associations of private or public interest), kind of unity (belonging to entrepreneurial or non-entrepreneurial companies), and generic affiliation (affiliation with corporations). 


\section{REFERENCES}

[1] Krasavchikov, O.A. (1998). The essence of a legal entity. Categories of civil law science. Moscow: Statut.

[2] On managing objects that are in state ownership: Law of Ukraine of September 21, 2006, No 185-V. Retrieved from https://zakon.rada.gov.ua/laws/show/185-16\#n310

[3] Kibenko, E.R. (1999). Corporate Law in Ukraine. Kharkiv: Espada.

[4] On banks and banking: Law of Ukraine of December 7, 2000 No 2121-III. Retrieved from https://zakon.rada.gov.ua/laws/show/2121-14

[5] On consumer cooperation: Law of Ukraine dated April 10, 1992, No 2265-XII. Retrieved from https://zakon.rada.gov.ua/laws/show/2265-12

[6] On public associations: Law of Ukraine dated March 22, 2012 No 4572-IV. Retrieved from https://zakon.rada.gov.ua/laws/show/4572-17

[7] On trade unions, their rights and guarantees of activity: Law of Ukraine dated September 15, 1999 No 1045-XII. Retrieved from https://zakon.rada.gov.ua/laws/show/1045-14

[8] On political parties: Law of Ukraine dated April 05, 2004 No 235-III. Retrieved from https://zakon.rada.gov.ua/laws/show/2365-14

[9] On charity work and charity organisations: Law of Ukraine dated July 5, 2002 No 5073VI. Retrieved from https://zakon.rada.gov.ua/laws/show/5073-17

[10] Zozulyak, O.I. (2017). Non-entrepreneurial legal entities as subjects of civil law: theoretical andpractical aspects. Ternopil: Pidruchniki I posibniki.

[11] Gorlov, V.A. (1998). Legal status of limited liability companies (Candidate thesis, Ural State Law Academy, Yekaterinburg, Russian Federation).

[12] On cooperation: Law of Ukraine of 10 July 2003 No 1087-IV. Retrieved from https:// zakon.rada.gov.ua/laws/show/1087-15

[13] On Civil associations: Law of Ukraine dated March 22, 2012 No 4572-IV. Retrieved from http://search.ligazakon.ua/1_doc2.nsf/link1/T124572.html

[14] Council Regulation (EC) No. 1435/2003 of 22 July 2003. Retrieved from https://minjust. gov.ua/m/str_45877

[15] On political parties: Law of Ukraine dated April 05, 2004 No 235-III. Retrieved from https://zakon.rada.gov.ua/laws/show/2365-14/ed20150808

[16] On charity work and charity organisations: Law of Ukraine dated July 5, 2002 No 5073VI. Retrieved from https://zakon.rada.gov.ua/laws/show/531/97-\%D0\%B2\%D1\%80

[17] Iyioke, I.V. (2018). Is it farcical defending corporate responsibility? Corporate Social Responsibility for Valorization of Cultural Organizations. Garrison: IGI Global.

[18] Jurkevičius, V., \& Pokhodun, Y. (2018). The doctrine of apparent authority as a precondition for sustainable business. Entrepreneurship and Sustainability Issues, 6(2), 649-661.

[19] Vida, I.C., \& Moroșteș, A. (2018). Clarifications on the legal terminology in the constitutional court jurisprudence. Journal of Legal Studies, 21(35), 88-94.

[20] Kuril, J. (2018). Protection of the state and society: Public administration and public (state) service. Journal of Security and Sustainability Issues, 7(3), 409-416.

\section{Farkhad S. Karagussov}

Doctor of Juridical Science, Professor

Institute of Private Law

Caspian University

050000, 521 Seyfullin Ave., Almaty, Republic of Kazakhstan 


\section{Anatoly V. Kostruba}

Doctor of Law, Associate Professor, Professor

Department of Civil Law

Vasyl Stefanyk Precarpathian National University

76018, 57 Shevchenko Str., Ivano-Frankivsk, Ukraine

Suggested Citation: Karagussov, F. S., \& Kostruba, A.V. (2018). Legal form of activity of legal entities of corporation type. Journal of the National Academy of Legal Sciences of Ukraine, 26 (2), 131-146.

Submitted: $12 / 03 / 2019$

Revised: 30/04/2019

Accepted: 20/06/2019 